FOKUS

Jurnal Kajian Keislaman

dan Kemasyarakatan
Institut Agama Islam Negeri (IAIN) Curup, Indonesia

ISSN 2548-334X (p); 2548-3358 (e)

volume 6, number 2, 2021 | page: 193-206

DOI: http://doi.org/10.29240/jf.v5i2.1892

\title{
Persepsi Ibu-Ibu Nasabah Terhadap Program Pembiayaan Paket Masa Depan Bank BTPN Syariah (Mobile Marketing Syariah) X Koto Tanah Datar
}

\author{
Yurri Trinanda, Damsar \& Bob Alfiandi \\ Pascasarjana Sosiologi Unand Padang, Indonesia \\ yuritrinanda90@gmail.com
}

\begin{abstract}
This study aims to determine the perceptions of women customer of the Bank BTPN Syariah MMS (Mobile Marketing Syariah) X Koto Tanah Datar Future Package financing program. The method used in this research is qualitative method. Data collection techniques: Observation, Interview and Documentation, Data Analysis: Miles Huberman. Bank BTPN Syariah unit MMS (Mobile Marketing Syariah) X Koto presents a future package financing program based on sharia principles which focuses its activities on providing business capital financing and aims to prosper underprivileged women in rural areas, especially (mothers) in X Koto Tanah Datar. The results showed that the implementation of the future package financing program for Bank BTPN Syariah MMS X Koto was not in accordance with sharia principles, the installment payment system was not affordable and the margin / profit received by the Bank was very high at $30 \%$ to $43 \%$. This has resulted in poor perceptions from customer mothers of future package financing programs.
\end{abstract}

Keywords: Perception of women customers, Bank BTPN Syariah MMS X Koto Future Package financing program.

Abstrak. Penelitian ini bertujuan untuk mengetahui persepsi ibu-ibu nasabah terhadap program pembiayaan Paket Masa Depan Bank BTPN Syariah MMS (Mobile Marketing Syariah) X Koto Tanah Datar. Metode yang digunakan dalam penelitian ini adalah metode kualitatif. Teknik pengumpulan data: Observasi, Wawancara dan Dokumentasi, Analisis Data: Miles Huberman. Bank BTPN Syariah unit MMS (Mobile Marketing Syariah) X Koto menghadirkan sebuah program pembiayaan paket masa depan yang berdasarkan prinsip syariah yang memfokuskan kegiatannya pada pemberian pembiayaan modal usaha dan bertujuan untuk mensejahterakan perempuan prasejahtera di pedesaan terutama (ibu-ibu) di X Koto Tanah Datar. Hasil penelitian menunjukkan bahwa pelaksanaan dari program pembiayaan paket masa depan Bank BTPN Syariah MMS X Koto ternyata tidak sesuai dengan prinsip syariah, sistem pembayaran angsuran tidak terjangkau dan margin/keuntungan yang diterima oleh Bank 
sangat tinggi sebesar 30\% sampai 43\%. Hal ini menimbulkan persepsi yang kurang baik dari ibu-ibu nasabah terhadap program pembiayaan paket masa depan.

Kata Kunci: Persepsi ibu-ibu nasabah, Program pembiayaan Paket Masa Depan Bank BTPN Syariah MMS X Koto

\section{Pendahuluan}

Bank merupakan lembaga keuangan yang mempunyai peranan sangat strategis dalam pembangunan nasional. Kegiatan utama dari perbankan adalah menyerap dan menyalurkan dana ke masyarakat. Dunia perbankan mengenal dua sistem yaitu sistem ekonomi konvensional dan sistem ekonomi syariah. Menurut Undang-Undang Perbankan Nomor 10 Tahun 1998 yang dimaksud dengan bank adalah adalah "badan usaha yang menghimpun dana dari masyarakat dalam bentuk simpanan dan menyalurkannya ke masyarakat dalam bentuk kredit atau bentuk lainnya dalam rangka meningkatkan taraf hidup masyarakat". 1

Bank syariah adalah bank yang menjalankan kegiatan usahanya berdasarkan prinsip syariah. Bank syariah memiliki fungsi menghimpun dana dari masyarakat dalam bentuk titipan dan investasi dari pihak pemilik dana, fungsi lainnya adalah menyalurkan dana kepada pihak lain yang membutuhkan dana dalam bentuk jual beli maupun kerja sama usaha. Pelaksanaan dari bank syariah mengacu pada hukum islam, dan tidak membebankan bunga maupun tidak membayar bunga kepada nasabah. Lahirnya bank syariah berkaitan dengan masalah keyakinan berupa riba, ketidakadilan dan moralitas dalam melakukan usaha. Penerapan bunga sebagai landasan operasional bank konvensional yang dianggap sebagai bentuk transaksi riba. Bunga diyakini mengandung unsur riba karena dalam sistem bunga terdapat unsur ketidakadilan karena pemilik dana mewajibkan peminjam dana untuk membayar lebih dari pada yang dipinjam tanpa memperhatikan apakah peminjam mengalami keuntungan atau kerugian, sehingga lahirlah bank syariah. Salah satu bentuk penyaluran dana pada bank syariah yaitu menggunakan akad murabahah. Akad murabahah merupakan transaksi jual beli yang dilakukan oleh pihak penjual dan pembeli atas barang dan jasa, pihak

\footnotetext{
${ }^{1}$ Kasmir. 2002. Dasar-Dasar Perbankan. Jakarta: PT Raja Grafindo Persada.
} 
penjual bank harus memberitahu pihak pembeli mengenai harga asal pembelian produk yang disepakati secara bersama. ${ }^{2}$

Beberapa kegiatan yang dikembangkan dari perbankan syariah adalah menumbuhkan kegiatan produksi masal berskala kecil dan menengah, khususnya di sektor argo industri melalui skema pembiayaan lunak (mikro) dengan menggunakan akad murabahah. Adanya bank syariah bertujuan agar dapat mendukung strategi pengembangan ekonomi regional, memfasilitasi segmen pasar yang belum terjangkau dan diharapkan memenuhi pembiayaan pada masyarakat yang membutuhkan melalui produk-produk penyaluran dana yang ditawarkan. Lembaga bank syariah sebagai bagian dari perekonomian negara mempunyai tugas penting dalam mendukung kegiatan ekonomi masyarakat agar dapat mengembangkan usaha. Dukungan tersebut yakni memberi kesempatan kepada masyarakat yang kekurangan modal untuk dapat mengakses dan memperoleh produk dan jasa perbankan seperti pinjaman modal dengan harga yang terjangkau, wajar, dan transparan. ${ }^{3}$

Dalam operasionalnya, Bank Syariah harus menyalurkan dana yang telah dihimpun dengan tepat guna dan sesuai dengan prinsip syariah islam. Dalam mengatasi kendala permodalan, lembaga keuangan syariah berlombalomba mengeluarkan produk pembiayaan untuk masyarakat. Salah satu lembaga keuangan syariah yaitu Bank BTPN Syariah. Pada tanggal 22 Mei 2014 Bank BTPN Syariah melaksanakan pembiayaan dalam bentuk usaha mikro kecil yang difokuskan untuk melayani segmen TUR (Tunas Usaha Rakyat). Pembiayaan mikro (TUR) tersebut memprioritaskan pemberdayaan juataan keluarga prasejahtera khususnya perempuan prasejahtera. Dalam menjalankan kegiatan penyaluran dana, Bank BTPN Syariah menghadirkan sebuah program pembiayaan paket masa depan (PMD). Program pembiayaan paket masa depan merupakan program pembiayaan terpadu bank BTPN Syariah yang diberikan kepada sekelompok wanita di pedesaan yang memiliki usaha untuk dikembangkan maupun bagi yang belum memiliki usaha tetapi mempunyai tekad untuk berusaha, memiliki mimpi untuk merubah hidup, tetapi tidak memiliki tambahan modal dan akses jaminan ke dunia perbankan. Program pembiayaan paket masa depan ini memberikan penekanan pada paket

\footnotetext{
${ }^{2}$ Antonio, Muhamad Syafi'i. 2001. Bank Syariah dari Teori ke Praktek. Jakarta: Gema Insani.

${ }^{3}$ Muhammad, 2005. Managemen Bank Syariah. Yogyakarta. Unit Penerbit dan percetakan (UPP) AMP YKPN.
} 
pembiayaan produktif yang bertujuan untuk memberdayakan jutaan keluarga pra/cukup sejahtera membangun kehidupan yang lebih baik. ${ }^{4}$

Produk paket masa depan Bank BTPN Syariah adalah paket pembiayaan dengan menggunakan akad murabahah yang meliputi: pembiayaan, tabungan, asuransi jiwa. Persyaratan dari program pembiayaan paket madsa depan yaitu perempuan, memiliki kelompok minimal 10 dan maksimal 15 orang, memiliki kartu tanda penduduk, kartu keluarga. Program pembiayaan paket masa depan memiliki fasilitas pembiayaan senilai Rp. 1.500 .000 sampai 10.000 .000 yang dibayarkan melalui cicilan setiap dua minggu, jangka waktu pembayaran diberikan selama 1 tahun (26 kali angsuran) dan 1,5 tahun (37 kali angsuran). ${ }^{5}$

Bank BTPN Syariah memiliki kantor cabang sebvagai perwakilan disetiap daerah yang diberi nama Mobile Marketing Syariah (MMS). Bank BTPN Syariah MMS X Koto merupakan Mobile Marketing Syariah yang dapat dikatakan sebagai kantor cabang dari bank BTPN Syariah yang penempatannya berada di Kecamatan, yang dikhususkan untuk melayani dan memberikan akses pinjaman modal untuk masyarakat berpenghasilan rendah khususnya ibu-ibu prasejahtera. Dalam pelaksanaannya Bank BTPN Syariah MMS X Koto melakukan sosialisasi kepada ibu-ibu dipedesaan untuk memperkenalkan program pembiayaan paket masa depan. Program pembiayaan paket masa depan Bank BTPN Syariah MMS X Koto memberikan kemudahan bagi ibu-ibu untuk memperoleh pembiayaan modal usaha yaitu tidak menggunakan jaminan. Program pembiayaan paket masa depan ini berdasarkan prinsip syariah yang bertujuan untuk membantu dan mensejahterakan ibu-ibu prasejahtera.

Pada kenyataanya, melalui hasil observasi dan wawancara dilapangan, penulis telah melihat banyak ibu-ibu nasabah yang bergabung dengan program pembiayaan paket masa depan Bank BTPN Syariah MMS X Koto mengeluh dan kecewa bahwa program pembiayaan tersebut tidak mensejahterakan mereka. Ibu-ibu nasabah kecewa bahwa pelaksanaan dari program pembiayaan paket masa depan Bank BTPN Syariah MMS X Koto tidak sesuai dengan prinsip syariah karena margin/keuntungan yang diterima bank sangat tinggi yaitu 30\% - 43\%, dan sistem pembayaran angsuran setiap 2 minggu tidak terjangkau oleh ibu-ibu nasabah. Ibu-ibu nasabah sangat berharap bahwa program pembiayaan paket masa depan Bank BTPN Syariah MMS X Koto ini benar-benar sesuai dengan prinsip syariah dan bertujuan untuk membantu dan mensejahterakan

${ }^{4}$ BTPN, Profil. Website, http://www.btpnsyariah.com/tentang-kami/profil di akses pada tanggal 25 Desember 2018.

${ }^{5}$ BTPN, Produk. Website, http://www.btpnsyariah.com/produk/ di akses pada tanggal 25 Desember 2018. 
kehidupan mereka. Namun kenyataannya hal tersebut tidak sesuai dengan yang dialami oleh ibu-ibu nasabah, sehingga menimbulkan persepsi dari ibu-ibu nasabah terhadap program pembiayaan paket masa depan Bank BTPN Syariah (Mobile Marketing Syariah) X Koto Tanah Datar. Tujuan penelitian ini akan mengungkap bagaimana persepsi ibu-ibu nasabah terhadap program pembiayaan paket masa depan Bank BTPN Syariah MMS X Koto Tanah Datar.

Penelitian terdahulu yang pernah dilakukan dan memiliki topik yang hampir sama dapat dijadikan referensi untuk memperkaya penelitian ini yaitu penelitian yang dilakukan oleh penelitian yang dilakukan oleh Okta Rizka (2017) yang berjudul Pengaruh Persepsi Nasabah dan Margin Terhadap Keputusan Pengambilan Pembiayaan Griya Pada Bank Syariah Mandiri KCP6

\section{Hasil dan Pembahasan}

\section{Gambaran Kecamatan $X$ Koto Tanah Datar}

Kecamatan X Koto berada di Kabupaten Tanah Datar Sumatera Barat yang terletak di Pulau Sumatera dan berada antara $0^{\circ} 23^{\prime} 38^{\prime \prime}$ dan $0^{\circ} 33^{\prime}$ 54" lintang selatan dan antara 100 18' 39" dan 100을 26' bujur timur. Kecamatan $\mathrm{X}$ Koto terletak didaerah yang cukup strategis dengan Luas $152,02 \mathrm{~km}^{2}$. Kecamatan X Koto terdiri dari 9 Nagari dan 41 jorong dengan Nagari terluas adalah Singgalang yang mencapai $39,46 \mathrm{~km}^{2} .^{7}$

Dari keseluruhan luas Kecamatan X Koto sebagian besar (33,39 \%) berupa hutan yang dilindungi oleh Pemerintah, sedangkan bangunan dan pekarangan adalah seluas $16,29 \mathrm{~km}^{2}(10,72 \%)$ dan yang digunakan untuk lahan persawahan seluas $16,64 \mathrm{~km}^{2}(10,95 \%)$. Kecamatan X Koto berbatasan langsung dengan kabupaten/kota lainnya. Adapun batas-batas wilayah Kecamatan X Koto yakni sebelah Utara Kabupaten Agam, Sebelah Selatan Kota Padang Panjang, Sebelah Barat Kecamatan Batipuh, Sebelah Timur Kabupaten Pariaman. Pada tahun 2018 jumlah penduduk Kecamatan X Koto mencapai 43.634 jiwa. Secara demografis Nagari Panyalaian mempunyai penduduk paling terbanyak yaitu berjumlah 9.446 jiwa yang terdiri dari 4.615 jiwa laki-laki dan 4.831 jiwa perempuan. Mayoritas masyarakat Kecamatan X Koto merupakan suku Minangkabau yang masih memegang nilai-nilai adat dan budaya tradisional. Sekalipun masih memegang nilai adat, akan tetapi masyarakat

6 Rizka Okta. 2017. Pengaruh Persepsi Nasabah dan Margin Terhadap Keputusan Pengambilan Pembiayaan Griya Pada Bank Syariah Mandiri KCP Teluk Betung. Bandar Lampung.

7 Badan Pusat Statistik. 2018. Kecamatan X Koto dalam Angka 2018. Tanah Datar. 
Kecamatan X Koto tetap terbuka terhadap berbagai perubahan sosial, hal ini dapat dilihat dengan tetap rukunnya kehidupan masyarakat Kecamatan X Koto etnis minangkabau dengan etnis non minangkabau. Mayoritas masyarakat Kecamatan X Koto beragama Islam. Mata pencaharian masyarakat Kecamatan $\mathrm{X}$ Koto terdiri dari PNS, wiraswasta, petani, pedagang, penjahit/ pengrajin songket, TNI/ Polri, dan buruh. ${ }^{8}$

Bank BTPN Syariah membuka kantor cabang sebagai perwakilan disetiap daerah yang diberi nama MMS (Mobile Marketing Syariah). Bank BTPN Syariah MMS X Koto didirikan pada tahun 2014 untuk melaksanakan segmen pembiayaan mikro, kantor cabang ini bertujuan melayani pengajuan pembiayaan untuk masyarakat khususnya perempuan yang berada di kecamatan X Koto. Bank BTPN Syariah MMS X Koto membentuk suatu tim sebagai perwakilan disetiap kecamatan di daerah. Adapun karyawan bank BTPN Syariah MMS X Koto terdiri dari 4 orang pembina sentra (marketing) dan dipimpin 1 orang manager sentra. Seluruh tim/ pegawai MMS adalah perempuan, dan BTPN Syariah juga secara eklusif hanya memberikan pembiayaan kepada masyarakat khususnya perempuan prasejahtera. ${ }^{9}$

\section{Persepsi Ibu-Ibu Nasabah Terhadap Program Pembiayaan Paket Masa Depan Bank BTPN Syariah MMS X Koto Tanah Datar}

Persepsi merupakan tanggapan atau penerimaan langsung dari seseorang. Menurut Jalaludin (2011) persepsi merupakan pengalaman tentang obyek, peristiwa atau hubungan-hubungan yang diperoleh dengan menyimpulkan informasi dan menafsirkan pesan. Menurut Bimo Walgito (2002) persepsi merupakan suatu proses yang didahului penginderaan yaitu proses stimulus oleh individu melalu proses sensoris. Analisis persepsi dalam penelitian ini dilakukan untuk melihat bagaimana persepsi ibu-ibu nasabah terhadap program pembiayaan paket masa depan Bank BTPN Syariah MMS X Koto. Persepsi muncul dari ibu-ibu nasabah setelah mereka bergabung dengan program pembiayaan paket masa depan Bank BTPN Syariah MMS X Koto. Banyak dari ibu-ibu nasabah bergabung, mereka berpersepsi bahwa program paket masa depan terdapat ketidaksesuaian antara tujuan awal program Bank dengan pelaksanaan program bank yang terjadi dilapangan. Persepsi ibu-ibu nasabah yang dilihat dibagi 2 yaitu 1). Persepsi ibu-ibu nasabah terhadap Margin/keuntungan Bank BTPN Syariah MMS X Koto, 2). Persepsi ibu-ibu

\footnotetext{
${ }^{8}$ Ibid

${ }^{9}$ BTPN Syariah MMS X Koto, 2020
} 
nasabah terhadap sistem pembayaran angsuran Bank BTPN Syariah MMS X Koto.

\section{Persepsi Ibu- Ibu Nasabah Terhadap Margin/Keuntungan}

Bank syariah sebagai lembaga keuangan yang berfungsi memperlancar mekanisme ekonomi di sektor riil melalui aktivitas usaha berdasarkan prinsip syariah. Namun banyak bank syariah menetapkan margin/keuntungan terhadap produk-produk pembiayaan dengan menggunakan akad pembiayaan murabahah. Margin/keuntungan adalah jumlah keuntungan yang ditetapkan oleh perbankan syariah berdasarkan biaya yang dikeluarkan dalam proses produksi dalam menetapkan harga jual suatu produk, biaya-biaya yang diperhitungkan pihak bank dalam melakukan transaksi dengan nasabah. Secara teknis margin/keuntungan adalah persentase tertentu yang diterapkan dalam perhitungan margin secara harian maka jumlah hari dalam setahun ditetapkan 360 hari dan secara bulanan, maka setahun ditetapkan 12 bulan. Pada umumnya, nasabah melakukan pembayaran secara angsuran, tagihan yang timbul sebagai transaksi disebut sebagai piutang, besarnya piutang tergantung pada plafon pembiayaan dari nasabah. Dalam penetapan margin/keuntungan pembiayaan dengan menggunakan akad Murabahah ini masih termaginalkan (tersisihkan) dan yang muncul kepermukaan adalah produk jual beli "mark up" yang tentunya masih dikhawatirkan publik sebagai upaya yang belum maksimal dijalankan oleh perbankan syariah. ${ }^{10}$

Dalam prakteknya bank syariah menentukan kebijakan margin/keuntungan yang diinginkan tidak terlepas dari rujukan (benchmark) kepada suku bunga konvensional, tingkat pesaing (competitor), dan lain-lain. Sehingga masih banyak terdapat kritikan-kritikan terhadap beberapa praktik yang dilakukan perbankan syariah terutama pada penentuan margin/keuntungan yang dianggap masih sama dengan kredit pada bank konvensional. Hal ini didasarkan pada kenyataan bahwa proses pembiayaan pada bank syariah menggunakan metode pembebanan bunga yang mengacu pada SBI (Suku Bunga Bank Indonesia) dan prinsip cost of fund yang merupakan pikiran utama dalam perbankan konvensional.

Bank BTPN Syariah MMS X Koto merupakan lembaga bank yang menjalankan prosedurnya berbasis syariah dan bertujuan memberikan modal pembiayaan usaha mikro untuk kebutuhan masyarakat terutama ibu-ibu prasejahtera. Pada kenyataannya Bank BTPN Syariah MMS X Koto telah menetapkan margin/keuntungan yang tinggi kepada ibu-ibu nasabah.

\footnotetext{
Gema Insani.
}

${ }^{10}$ Muhamad Syafi'i Antonio. 2001. Bank Syariah dari Teori ke Praktek. Jakarta: 
Penetapan margin/keuntungan yang diberikan oleh Bank BTPN Syariah tersebut sama dengan produk pembiayaan kredit berbunga flat pada bank konvensional. Adapun perhitungan penentuan margin/keuntungan yang diperoleh Bank BTPN Syariah MMS X Koto dapat dilihat dari table 1 berikut ini:

Tabel 1. Rincian Margin/Keuntungan Bank BTPN Syariah

\begin{tabular}{|c|c|c|c|c|c|}
\hline \multicolumn{5}{|c|}{ Pembiayaan Paket Masa Depan (PMD) } \\
\hline Tenor 1 Tahun & \multicolumn{3}{c|}{ Tenor 1,5 Tahun } \\
\hline Plafon & Margin & Total & Plafon & Margin & Total \\
\hline 1.500 .000 & 450.000 & 1.950 .000 & 1.500 .000 & 572.000 & 2.072 .000 \\
\hline 2.000 .000 & 600.000 & 2.600 .000 & 2.000 .000 & 886.000 & 2.886 .000 \\
\hline 3.000 .000 & 900.000 & 3.900 .000 & 3.000 .000 & 1.329 .000 & 4.329 .000 \\
\hline 4.000 .000 & 1.200 .000 & 5.200 .000 & 4.000 .000 & 1.772 .000 & 5.722 .000 \\
\hline 5.000 .000 & 1.500 .000 & 6.500 .000 & 5.000 .000 & 2.215 .000 & 7.215 .000 \\
\hline 6.000 .000 & 1.800 .000 & 7.800 .000 & 6.000 .000 & 2.658 .000 & 9.658 .000 \\
\hline 7.000 .000 & 2.100 .000 & 8.100 .000 & 7.000 .000 & 3.101 .000 & 10.101 .000 \\
\hline 8.000 .000 & 2.400 .000 & 10.400 .000 & 8.000 .000 & 3.544 .000 & 11.544 .000 \\
\hline 9.000 .000 & 2.700 .000 & 11.700 .000 & 9.000 .000 & 3.987 .000 & 12.987 .000 \\
\hline 10.000 .000 & 3.000 .000 & 13.000 .000 & 10.000 .000 & 4.430 .000 & 14.430 .000 \\
\hline
\end{tabular}

Sumber: Bank BTPN Syariah MMS X Koto, 2020

Berdasarkan tabel diatas, penetapan margin/keuntungan yang diperoleh Bank BTPN Syariah MMS X Koto sebesar 30 \% sampai 43 \%. Padahal Bank BTPN Syariah MMS X Koto menggunakan akad murabahah. Dimana akad murabahah adalah suatu pembiayaan dengan akad jual beli barang pada harga asal yang disepakati oleh pihak bank dan nasabah. Namun pada tabel diatas bahwa penetapan margin/keuntungan dari Bank BTPN Syariah berdasarkan plafon yang ditawarkan kepada nasabah, bukan berdasarkan harga barang. Maka tidak ada bedanya margin/keuntungan yang terdapat dari plafon pembiayaan paket masa depan Bank BTPN Syariah MMS X Koto dengan bunga pada bank konvensional.

Pada saat sosialisasi pihak bank hanya menjelaskan keunggulan dan kemudahan yang menarik dari program pembiayaan paket masa depan yaitu salah satunya bahwa Bank BTPN Syariah menjalankan prosedurnya sesuai prinsip syariah islam, artinya tidak memperoleh keuntungan (riba). Namun yang terjadi bahwa pihak Bank BTPN Syariah tidak memberitahu dan menutupi berapa penetapan margin/keuntungan sebenarnya yang diterima oleh Bank. Margin/keuntungan yang diterima oleh Bank BTPN Syariah MMS X Koto merupakan hal yang tidak wajar, karena pembiayaan diberikan berdasarkan prinsip syariah dan untuk ibu-ibu nasabah prasejahtera. 
Penulis menemukan dilapangan bahwa margin/keuntungan yang diperoleh Bank BTPN Syariah sangat tinggi. Hal ini dapat dibuktikan melalui rincian hitungan pembiayaan dari 2 orang ibu-ibu nasabah sebagai berikut:

a) Ibu Yeni sebagai nasabah Bank BTPN Syariah MMS X Koto mengajukan pembiayaan untuk berjualan makanan dan lontong sebesar Rp.5.000.000. Pihak bank menyetujui dengan jangka waktu 1 tahun, penetapan margin/keuntungan 30\% per tahun dan dicicil setiap 2 minggu. Dapat dilihat dibawah ini perhitungan pembiayaan dari ibu Yeni sebagai berikut:

$$
\begin{array}{lll}
\text { Hutang Pokok } & =\text { Rp.5.000.000 } & \text { Jangka Waktu }=12 \text { Bulan } \\
\text { Margin/Keuntungan } & =\text { Rp.1.500.000 }+ & \text { Margin } / \text { Keuntungan }=30 \% \\
\text { Total Hutang Nasabah } & =\text { Rp 6.500.0000 } & \text { Per Tahun (Pokok \& Margin) } \\
\text { Angsuran Per 2 minggu } & =\text { Rp 260.000 } &
\end{array}
$$

b) Ibu Nuraina sebagai nasabah Bank BTPN Syariah MMS X Koto mengajukan pembiayaan untuk usaha tenun songket dan bertani sebesar Rp. 5.000.000. Pihak bank menyetujui dengan jangka waktu 1,5 tahun, penetapan

\begin{tabular}{|c|c|c|}
\hline Hutang Pokok & $=$ Rp.5.000.000 & Jangka Waktu = 18 Bulan \\
\hline Margin/Keuntungan & $=$ Rp.2.215.000+ & Margin $/$ Keuntungan $=43 \%$ \\
\hline Total Hutang Nasabah & $=\operatorname{Rp} 7.215 .000$ & per Tahun (Pokok \& Margin) \\
\hline
\end{tabular}
margin/keuntungan $43 \%$ per tahun dan dicicil setiap 2 minggu. Dapat dilihat di bawah ini perhitungan pembiayaan dari Ibu Nuraina sebagai berikut:

Dari penjelasan diatas dapat diketahui bahwa perolehan margin/ keuntungan dari Bank BTPN Syariah MMS X Koto yaitu 30\% sebesar Rp 1.500.000 ( 1 tahun) dan 43 \% sebesar Rp 2.215.000 (1,5 tahun). Setelah ibuibu nasabah bergabung dan melakukan transaksi pembayaran angsuran, mereka berpersepsi bahwa penetapan margin/keuntungan dari Bank BTPN Syariah MMS X Koto sangat tinggi. Hal ini menimbulkan persepsi yang kurang baik dari ibu-ibu nasabah, mereka kecewa karena telah dibohongi oleh Bank BTPN Syariah MMS X Koto. Hal ini sesuai diungkapkan oleh ibu Yeni (40 Tahun):

"Setelah ibuk hitung-hitung bunga di bank BTPN ini, ya besar sekali bunganya. Padahal dulu disampaikan ini bank syariah tidak ada 
memperoleh keuntungan. Namun besar juga ibuk membayar angsuran jadinya. Kalau seperti ini sama saja tidak menolong ibuk".

Hal ini juga sesuai yang diungkapkan oleh Ibu Nuraina (50 tahun)

"Semenjak ibuk membayar angsuran sudah 3 kali, baru terasa sama ibuk kalau bunga yang diperoleh oleh bank ini besar. Sudah ibuk lihat di kartu angsuran dan ibuk hitung-hitung semuanya ternyata besar ibuk membayar, dari ibuk meminjam 5.000.000, keuntungan yang diperoleh bank ini sebesar Rp 2.215.000".

Ibu-ibu nasabah berpersepsi bahwa perolehan margin/keuntungan dari Bank BTPN Syariah tidak sesuai dengan kenyataan sebenarnya. Ibu-ibu nasabah baru menyadari dan kecewa kalau keuntungan yang diterima bank BTPN Syariah tergolong tinggi, hal tersebut tentunya dapat merugikan pihak nasabah. Sebaiknya bank BTPN Syariah sebagai penyalur pembiayaan harus memberitahukan secara jujur tentang perolehan margin/keuntungan sebenarnya, bukan dengan cara membohongi ibu-ibu nasabah.

Penetapan margin/margin dapat dilakukan dengan cara Rasulullah ketika berdagang. Dalam menentukan harga penjualan, Rasul secara transparan menjelaskan berapa harga belinya, berapa biaya yang telah dikeluarkan untuk setiap komoditas dan berapa keuntungan wajar yang diinginkan. Cara yang dipakai oleh Rasulullah ini dapat dipakai sebagai salah satu metode bank BTPN Syariah dalam menentukan

\section{Persepsi Ibu-Ibu Nasabah Terhadap Sistem Pembayaran Angsuran}

Menurut Kamus Besar Bahasa Indonesia (KBBI), Angsuran yaitu uang yang dipakai untuk mengangsur atau cicilan. Angsuran adalah uang yang dipakai untuk diserahkan sedikit demi sedikit atau tidak sekaligus, seperti untuk pembayaran utang, pajak dan sebagainya. Sistem angsuran merupakan suatu pembayaran atau pelunasan atas uang, barang dan jasa secara bertahap atau berkala dengan cicilan (pembayaran) sebagian dengan besar pembayaran dan jangka waktunya telah ditentukan sesuai kesepakatan kedua belah pihak yang membayar dan penerima pembayaran. Intinya sistem pembayaran angsuran berhubungan dengan proses pembayaran akan sesuatu seperti jasa, barang, tagihan, dan lainnya. ${ }^{11}$

${ }^{11}$ Kasmir. 2002. Dasar-Dasar Perbankan. Jakarta: PT Raja Grafindo Persada. 
Program pembiayaan paket masa depan Bank BTPN Syariah MMS X Koto menggunakan sistem pembayaran angsuran selama 1 bulan 2 kali atau pembayaran angsuran dibayarkan melalui cicilan setiap 2 minggu dan jangka waktu pembayarannya minimal 1 tahun (26 kali angsuran) maksimal 1,5 tahun (37 angsuran) yang dibayarkan saat pertemuan rutin sentra (PRS). Semua kegiatan harus dilakukan pada saat pertemuan rutin sentra dan dilakukan ditempat yang telah disepakati bersama oleh ibu-ibu nasabah. Adapun perhitungan sistem pembayaran angsuran yang dilaksanakan oleh Bank BTPN Syariah MMS X Koto dapat dilihat dari tabel 2:

Tabel 2. Sistem Pembayaran Angsuran Bank BTPN Syariah

\begin{tabular}{|c|c|c|c|}
\hline \multicolumn{4}{|c|}{ Pembiayaan Paket Masa Depan (PMD) } \\
\hline \multicolumn{2}{|c|}{ Tenor 1 Tahun } & \multicolumn{2}{c|}{ Tenor 1,5 Tahun } \\
\hline Plafon/ Pembiayaan & Angsuran & Plafon/ Pembiayaan & Angsuran \\
\hline 1.500 .000 & 78.000 & 1.500 .000 & 52.000 \\
\hline 2.000 .000 & 104.000 & 2.000 .000 & 76.000 \\
\hline 3.000 .000 & 156.000 & 3.000 .000 & 117.000 \\
\hline 4.000 .000 & 208.000 & 4.000 .000 & 156.000 \\
\hline 5.000 .000 & 260.000 & 5.000 .000 & 195.000 \\
\hline 6.000 .000 & 312.000 & 6.000 .000 & 234.000 \\
\hline 7.000 .000 & 364.000 & 7.000 .000 & 273.000 \\
\hline 8.000 .000 & 416.000 & 8.000 .000 & 312.000 \\
\hline 9.000 .000 & 468.000 & 9.000 .000 & 351.000 \\
\hline 10.000 .000 & 520.000 & 10.000 .000 & 390.000 \\
\hline
\end{tabular}

Sumber: Bank BTPN Syariah MMS X Koto

Berdasarkan tabel diatas, sistem pembayaran angsuran yang dilaksanakan Bank BTPN Syariah MMS X Koto yaitu setiap 2 minggu dengan jumlah angsuran yang berbeda-beda pada setiap plafon/pembiayaan nasabah. Sistem pembayaran angsuran setiap 2 minggu merupakan prosedur dan ketentuan dari Bank BTPN Syariah. Pada saat pre marketing dan pelatihan, pihak bank menyampaikan bahwa sistem pembayaran angsuran setiap 2 minggu sangat mudah dan terjangkau untuk ibu-ibu nasabah. Oleh karena itu pihak bank yakin bahwa nasabah pasti mampu melaksanakan aturan dan prosedur sistem pembayaran angsuran setiap 2 minggu dengan jumlah angsuran yang terjangkau. Di akhir periode, jika nasabah memiliki track record bagus selama masa pembayaran angsuran yang berarti membayar angsuran dengan tepat waktu, maka dapat kembali mengajukan dan menerima pembiayaan. 
Penulis menemukan dilapangan bahwa sistem pembayaran angsuran dari Bank BTPN Syariah MMS X Koto cepat dan jumlah angsurannya tidak terjangkau oleh ibu-ibu nasabah. Hal ini dapat dibuktikan melalui salah satu gambar buku angsuran yang digunakan oleh nasabah sebagai berikut:

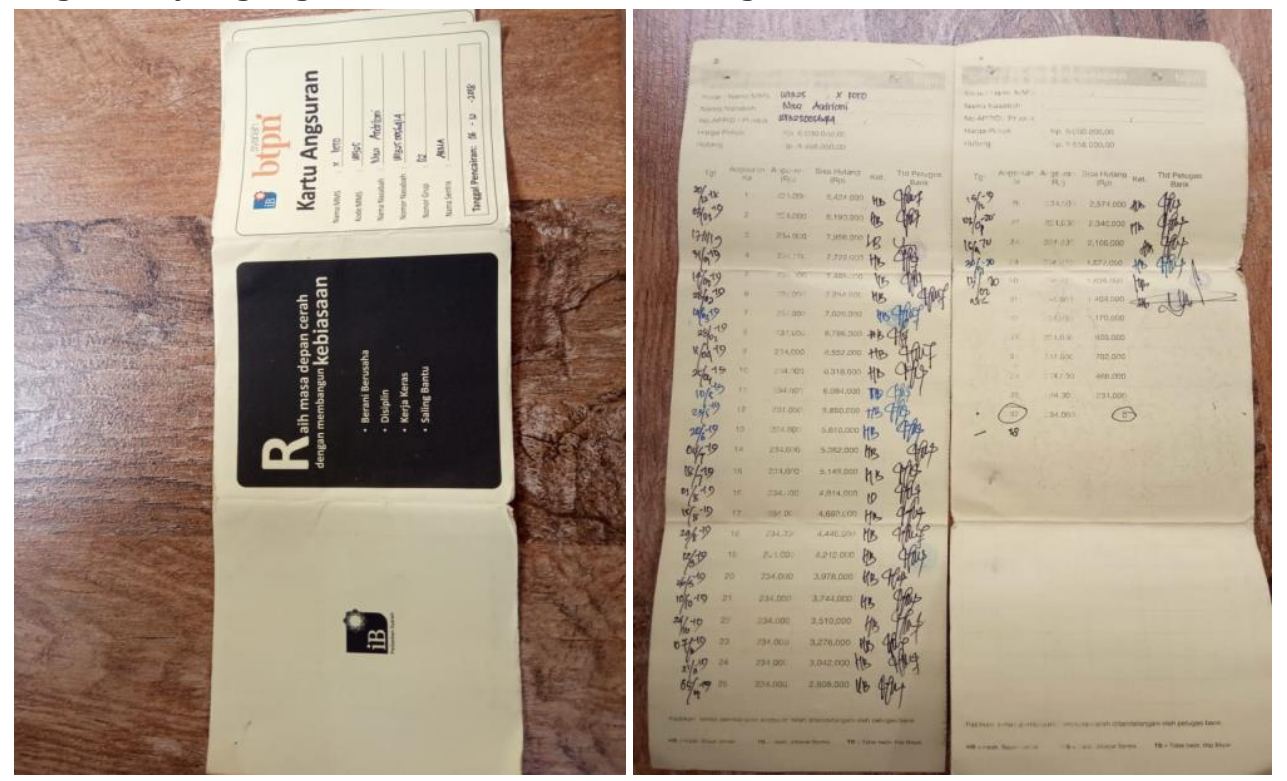

Gambar 1. Kartu Angsuran Bank BTPN Syariah

Pada gambar 1. ditampilkan buku angsuran salah satu nasabah atas nama Nita Andriani. Angsuran yang dibayar oleh ibu Nita setiap 2 minggu yaitu Rp 234.000. Pada buku angsuran dan penjelasan diatas, jelas bahwa sistem pembayaran angsuran dari Bank BTPN Syariah MMS X Koto yaitu setiap 2 minggu, dimana nasabah diwajibkan untuk membayar angsuran dengan tepat waktu dan sesuai ketentuan yang diberikan oleh Bank. Namun setelah ibu-ibu nasabah bergabung mereka berpersepsi bahwa sistem pembayaran angsuran setiap 2 minggu sangat berbeda dan tidak sesuai dengan yang dialami oleh ibuibu nasabah. Berdasarkan hasil wawancara peneliti dengan 4 orang ibu-ibu nasabah yang berpersepsi mengenai sistem pembayaran angsuran dari Bank BTPN Syariah MMS X Koto. Hal ini yang diungkapkan oleh ibu Yenita (39 Tahun):

“Waktu itu ibuk diberi informasi oleh petugas bank kalau membayar angsuran setiap 2 minggu ini mudah oleh ibuk. Namun setelah ibu jalani ternyata angsuran setiap 2 minggu ini waktunya terlalu cepat sekali. Ibuk merasakan sekali angsuran sebesar Rp 156.000 dalam waktu 2 minggu ini sangat cepat serta lumayan besar juga". 
Hal ini sesuai diungkapkan oleh Ibu Nita Andriani (42 tahun),

"Pihak Bank menyampaikan bahwa angsuran setiap 2 minggu ini sanggup oleh ibuk, ternyata tidak seperti itu. Ibuk merasakan waktu membayar angsuran setiap 2 minggu ini cepat sekali dan jumlah angsuran sebesar Rp 234.000 ini lumayan besar oleh ibuk".

Ibu-ibu nasabah berpersepsi bahwa sistem pembayaran angsuran dari Bank BTPN Syariah MMS X Koto tidak sesuai dengan kenyataan sebenarnya. Bank BTPN Syariah menjelaskan bahwa sistem pembayaran angsuran setiap 2 minggu sangat mudah dan terjangkau untuk nasabah. Namun yang terjadi dilapangan, ibu-ibu nasabah merasakan bahwa sistem pembayaran angsuran dari Bank BTPN Syariah MMS X Koto tersebut sangat cepat dan angsurannya tidak terjangkau.

\section{Bibliografi}

Afrizal. 2014. Metode Penelitian Kualitatif (Suatu Upaya Mendukung Penggunaaan Penelitian Kualitatif Dalam berbagai Disiplin Ilmu). Jakarta: PT Rajagrafindo Persada.

Acfira, Lukytta Gusti. 2014. Pengaruh Persepsi Nasabah Terhadap Pengambilan Pembiayaan Murabahah pada Bank BNI Syariah. Makasar.

Antonio, Muhamad Syafi'i. 2001. Bank Syariah dari Teori ke Praktek. Jakarta: Gema Insani.

Badan Pusat Statistik. 2018. Kecamatan X Koto dalam Angka 2018. Tanah Datar.

BTPN, Produk. Website, http://www.btpnsyariah.com/produk/ di akses pada tanggal 25 Desember 2018.

BTPN, Profil. Website, http://www.btpnsyariah.com/tentang-kami/profil di akses pada tanggal 25 Desember 2018.

Huda, Komarul dan Rokmat Subagiyo, 2015. Analisis Kesesuaian Harapan dan Persepsi Atas Kualitas Layanan pada Bank Umum Syariah. Tulungagung.

Kasmir. 2002. Dasar-Dasar Perbankan. Jakarta: PT Raja Grafindo Persada.

Maleong, J Lexy. 2002. Metode Penelitian Kualitatif Edisi Revisi. Bandung: PT. Remaja Pos Dakrya.

Muhammad, 2005. Managemen Bank Syariah. Yogyakarta. Unit Penerbit dan percetakan (UPP) AMP YKPN. 
206 | FOKUS: Jurnal Kajian Keislaman dan Kemasyarakatan, vol. 6, no. 2, 2021

Modul BTPN Syariah. 2015. Aduhai Panduan untuk Tim MMS Produktif. Jakarta: BTPN Syariah.

Rahmat, Jalaluddin.2011. Psikologi Komunikasi. Bandung: PT Remaja Rosda Karya Ofset.

Riska Okta. 2017. Pengaruh Persepsi Nasabah dan Margin Terhadap Keputusan Pengambilan Pembiayaan Griya Pada Bank Syariah Mandiri KCP Teluk Betung. Bandar Lampung.

UU Tentang Perbankan Negara Republik Indonesia No 10 Tahun 1998.

Walgito, Bimo.2002. Pengantar Psikologi Umum. Yogyakarta: Andi Ofset. 